\title{
Families and Health: A Review
}

\author{
Karsten Hank and Anja Steinbach
}

\section{Introduction}

Social scientists interested in individuals' health (and health inequalities) may take two - complementary - general perspectives: a life-course perspective (e.g., Kuh et al. 2003) and a contextual perspective (in which relevant social contexts may be defined at very different levels of aggregation, ranging from personal social networks to welfare states; e.g., Deindl et al. 2016). Arguably, the family context not only constitutes a core element of most individuals' social network structure, it also accompanies the individual across the entire life-course. Understanding the role of family in shaping individuals' health thus seems an important task, one which has received considerable attention in various social science disciplines (for recent reviews see Arránz Becker et al. 2017; Carr et al. 2014; Rapp and Klein 2015).

In this review, we basically follow the World Health Organization's definition of health as "a state of complete physical, mental and social well-being and not merely the absence of disease or infirmity", that is, health is conceptualized as a multidimensional outcome with objective and subjective components. The role of family in health is considered from the adult's perspective [focusing on partnership (Section "Partnership and Adult Health") and parenthood (Section "Parenthood and Adult Health")] as well as from the child's perspective [focusing on the consequences of parental separation and divorce (Section "Family Structure and Child

\footnotetext{
K. Hank (ه)

Institute of Sociology and Social Psychology, University of Cologne,

Cologne, Germany

e-mail: hank@wiso.uni-koeln.de
}
A. Steinbach
Institute of Sociology, University of Duisburg-Essen, Duisburg, Germany
e-mail: anja.steinbach@uni-due.de
(C) The Author(s) 2018
G. Doblhammer and J. Gumà (eds.), A Demographic Perspective on Gender,
Family and Health in Europe, https://doi.org/10.1007/978-3-319-72356-3_3 
Well-Being")]. We also review findings from research addressing the association of childhood circumstances (Section "Childhood Circumstances and Later Life Health") and intergenerational family relations (Section "Intergenerational Family Relations and Health") with health. This chapter concludes with a brief outlook on directions for future research (Section "Conclusions and Future Directions"). While our primary interest is on universal relationships between individuals' family context (histories, respectively) and different health outcomes, we are well aware of possible cross-national variations. Because in many cases the empirical evidence available is predominantly based on studies from the United States, we explicitly seek to include an overview of European research.

\section{Partnership and Adult Health}

Marriage has long been suggested to have a protective effect on health (including survival; for reviews see Koball et al. 2010; Rendall et al. 2011). Such a causal effect is said to result from both economic advantages and social support inherent in a marriage. Men in particular are purported to enjoy health benefits, as they tend to engage in healthier and less risky behaviors once married (e.g. drinking less alcohol and driving more carefully). However, caution is necessary: First, married people may overestimate their health, and the protective effect that marriage accords may diminish at the most severe levels of health (Zheng and Thomas 2013). Second, even more importantly, selection effects are likely to play a role here, as better health may affect one's chances to get (and remain) married. Healthier individuals may be more likely to possess characteristics such as a higher socio-economic status or greater physical attractiveness, making them more desirable (and more stable) marriage partners than those in poor health.

Even if selection is accounted for, a salutary effect of being married for a variety of physical and mental health outcomes has been demonstrated repeatedly (but see Kalmijn 2017). More recently, effects of changes in marital status and the consideration of marital biographies have received growing attention (e.g., Dupre and Meadows 2007; Hughes and Waite 2009). One important finding from this research is that dimensions of health which develop rather slowly, such as chronic conditions or mobility limitations, tend to be more strongly affected by marital history (pointing to the importance of time spent in a specific status), whereas others, such as depressive symptoms, seem to react more sensitively to current marital status.

Divorce has long been suggested to bring about negative short- and long-term effects on health, even among those who remarried (e.g., Lorenz et al. 2006). A recent European study, however, provides evidence for heterogeneous (that is, gendered) effects of union dissolution on self-assessed health: While for men separation more 
often leads to increases rather than decreases in health, women fare worse more often than well just after union dissolution (Monden and Uunk 2013). Gendered social pathways also seem to exist, if the reverse causal relationship is considered: Karraker and Latham (2015) found that only wives' onset of serious physical illness is associated with an elevated risk of divorce. There appear to be no gender differences, though, if the relationship between widowhood and health (specifically depression) is considered (e.g., Sasson and Umberson 2014; Schaan 2013). Across marital groups, the continuously married are better off compared to the widowed, whereas early (long-term) widowhood is associated with worse outcomes than late widowhood. Moreover, individuals reporting higher marital quality at baseline experience larger increases in the number of symptoms of depression after having entered widowhood than those with lower marital quality (see Walker and Luszcz 2009, for a review).

Along the same lines, Hank and Wagner (2013) found that having a partner does not contribute to greater psychological well-being per se: Only those reporting satisfaction with the extent of reciprocity in their relationship report lower numbers of depression symptoms than their unmarried counterparts. There is also evidence that marital strain accelerates the typical decline in self-rated health occurring over the life-course. This adverse effect has been shown to be similarly strong in men and women and to be greater at older ages (Umberson et al. 2006; also see Xu et al. 2016). Staying unhappily married may even be more detrimental to health than divorcing, as people in low-quality marriages were found to exhibit lower levels of overall well-being, largely independent of whether they remain unmarried or remarry (see Hawkins and Booth 2005).

Effects of marriage (marital history) on mortality have been investigated in the US (e.g., Henretta 2010; Rendall et al. 2011) as well as in a variety of European settings (e.g., Blomgren et al. 2012; Brockmann and Klein 2004). There is a consistent survival advantage of being married over unmarried both for women and-particularly-for men. Little evidence, however, is found for mortality differences between never-married, divorced/separated, and widowed statuses (see Shor et al. 2012a, b, for recent meta-analyses). Into an individual's current status, the marital biography has also been shown to be relevant: For example, multiple transitions into and out of marriage as well as a lower proportion of adult life spent married have been found to be associated with a higher hazard of dying after age 50 (also if current marital status is controlled for), even though the relationship tends to weaken at older ages.

Finally, although there appears to be some universality in the marriage-healthnexus reported above, it still seems important to situate marriage cohorts in their specific historical social contexts (cf. Newton et al. 2014; Schaan 2013). This also includes accounting properly for the growing complexity of relationship histories, that is, considering marriage alone is no longer sufficient to understand how living with (or without) a partner affects health (e.g., Schneider et al. 2014). 


\section{Parenthood and Adult Health ${ }^{1}$}

Closely intertwined with individuals' partnership histories (and their association with adult health) is the reproductive history and the parenthood-health-nexus (cf. O'Flaherty et al. 2016; Kravdal et al. 2012). Two causal mechanisms have been suggested to drive the relationship between individuals' fertility and later life health outcomes including survival (see, for example, Grundy and Tomassini 2005; Mirowsky 2005; Henretta 2007). First, there is evidence for biological effects, that is, direct long-term physiological and psychological implications of women's reproductive history on particular diseases. Most notably, breast cancer as well as other cancers of the female reproductive system were shown to be associated with pregnancy, childbirth, and lactation (see Grundy and Kravdal 2010, for a recent analysis).

Second, childbearing has been proposed to be related to a variety of social factors that might have both positive and negative effects on women's and men's health in later years. Specifically, differences in socio-economic status, social relationships, and health behaviors across the life-course have been put forward as being potentially relevant in this regard (e.g., Grundy and Tomassini 2005; Henretta 2007; Kendig et al. 2007). Having children may lead to economic strain, and particularly early as well as non-marital childbearing are likely to be related to lower socio-economic status and poorer family functioning over the life course (cf. Mirowsky and Ross 2002; Koropeckyj-Cox et al. 2007). There also is considerable potential for role overload and stresses related to raising children, particularly among lone parents. This, however, is contrasted by potentially health enhancing aspects of parenthood, such as greater opportunities for community participation and social support by children in later life. Moreover, parenthood may be associated with incentives - and social pressures - to adopt healthier behaviors (e.g., Fletcher 2012; Perales et al. 2015). The net effect of these factors not only varies according to individuals' socio-economic circumstances, but also with particular fertility pathways (e.g. the timing of births).

The relative importance of these biological and social mechanisms in determining the childbearing-health-nexus is still poorly understood (cf. Grundy and Read 2015). Causal analysis is further complicated by a range of possible selection effects, that is, by factors affecting both fertility and health. For example, individuals with a poor initial health endowment may not only be less fecund than their healthier counterparts, but they are also less likely to marry; i.e., their opportunities to become a parent and to enjoy the health benefits of marriage are reduced as well (see Section "Partnership and Adult Health" for details).

Although there is empirical evidence for a differential effect of childbearing (particularly timing of births) on specific physical health outcomes, such as diabetes, cardiovascular disease, or cancer (e.g., Alonzo 2002; Henretta 2007), many studies have used composite health indices or other general health measures, such as individuals' self-rated health (e.g., Hank 2010; Mirowsky 2005; Sudha et al.

\footnotetext{
${ }^{1}$ This section draws heavily on Hank (2010: 277-278).
} 
2006). Findings suggest that high parity (six or more children), early first birth, and the experience of infant death or pregnancy loss are associated with worse self-reported health at older ages. Early childbearing also bears a clear positive correlation with the prevalence of limitations in activities of daily living, whereas no significant effects of high parity were found. Looking at the presence of limiting long term illness, Grundy and Tomassini (2005) reported higher risks among older women with five or more children and those who had a teenage birth. Controlling for parity, mothers with short birth intervals were more likely to experience long term illness, whereas those who had a late birth (at age 40 or later) exhibited a reduced risk. Mirowsky (2005), however, reported a steep increase in later life general health problems among women who delayed their first birth beyond age 40 .

Unlike other major social roles, a clear relationship between parenthood and psychological well-being (depression) could not be identified by previous research (e.g. Evenson and Simon 2005; Hank and Wagner 2013; Kruk and Reinhold 2014). Some studies suggest that older childless men and women exhibit lower levels of depressive symptoms than parents, particularly if they are compared to those who had their first child early (e.g. Henretta et al. 2008) or whose relationship with their offspring is of poor quality (e.g. Koropeckyj-Cox 2002). More recently, however, Huijts et al. (2013) found that being childless is associated with worse psychological well-being for men (but not for women). Also, Grundy et al. (2017) showed that in Eastern, but not Western, European countries childlessness and having one compared with two children were associated with more depressive symptoms.

Studies dealing with individuals' childbearing histories and mortality (for reviews see Högnäs et al. 2017; Hurt et al. 2006) generally suggest that early childbearing tends to be associated with a higher hazard of dying, whereas late children enhance women's longevity (e.g., Doblhammer 2000; Mirowsky 2005; Henretta 2007). ${ }^{2}$ Grundy and Kravdal (2008), however, reported a positive association between earlier parenthood and later mortality as well as a reverse association with late age at last birth in Norway (with similar results for both men and women). Moreover, the authors found an overall negative association between higher parity and mortality, which is only partially consistent with Doblhammer (2000), for example, who showed for England/Wales and Austria that childless women and those with three or more children experienced excess mortality (also see Grundy and Tomassini 2005). Henretta (2007), however, did not find evidence for an effect of the number of children ever born on mortality. It seems important to keep in mind that even if the influence of reproductive history on longevity is statistically significant, it generally "is small compared to differences in longevity stemming from environmental factors such as level of education or family status" (Doblhammer 2000: 175; also see Hurt et al. 2006).

Recent evidence indicates that the fertility-health-nexus described above might vary across different societal contexts (e.g., Grundy 2009; Grundy and Foverskov 2016; Hank 2010). Along these lines, Grundy and Kravdal (2008) suggested that

\footnotetext{
${ }^{2}$ See Christiansen (2014) for an investigation of the association between grandparenthood and mortality.
} 
'family friendly' policies — such as generous parental leave regulations (cf. Aitken et al. 2015; also see Guertzgen and Hank 2018) — may have resulted in long-term health benefits for parents.

\section{Family Structure and Child Well-Being}

In addition to child maltreatment (see Greenfield 2010; Oswald et al. 2010; Prosser and Corso 2007 for reviews), parental separation and divorce have been identified as major family-related threats to children's health or-more generallywell-being. Following Moore et al. (2014), four dimensions of child well-being may be distinguished: (a) Physical well-being refers to children's overall physical health. (b) Psychological well-being reflects how children think about themselves, their future, and how they manage their emotions and situational demands. Specific aspects of psychological well-being include internalizing and externalizing behavioral problems, prosocial behavior and depression, perception of stress, self-worth, perceived autonomy, and participation. (c) Social well-being is related to how comfortable children are with social relationships. Of foremost importance are parent-child relationships (involving both biological and step relations), especially positive communication and other elements of good relationship climate. It also includes, however, the quality of peer relations. (d) Cognitive and educational wellbeing encompasses children's learning abilities and their utilization of educational opportunities, which also bear a close association with (long-term) health outcomes. Increasingly, the focus has expanded from a deficit-oriented approach-involving, for example, deprivation, risk behaviors, and the absence of health-to positive quality of life outcomes from the child's perspective.

Empirical studies - primarily from the US - generally indicate that children with separated or divorced parents tend to score worse than children who live with both biological parents on measures of a range of behavioral, emotional, social, or cognitive outcomes (for overviews see Amato 2010; Jeynes 2006; Sweeney 2010) and the resulting inequalities have been shown to - potentially-last through adulthood (Kalmijn 2008, 2013; Klaus et al. 2012; Steinbach 2013). Because the majority of theoretical approaches employed to explain the differences in child well-being among nuclear, single-parent, and separated/divorced families rely at least in part upon concepts of stress, coping, risk and resilience, Amato (2000: 1271) suggested an integrating 'divorce-stress-adjustment perspective'. From this perspective (which can easily be extended to include separation), the parents' divorce is not a singular event but rather a long-term developmental process that begins when the parents are still married and ends usually years after the legal act. In the underlying explanatory model of the divorce-stress-adjustment perspective, the divorce decree itself has minimal direct effects on children's well-being but the stressors und strains that accompany the divorce can indeed increase the likelihood of psychological, behavioral, and health problems for children. However, many factors moderate children's reactions and the speed of their adjustment to parental divorce. 
The well-being of children with separated or divorced parents is at threat from stressors affecting parents and children (e.g., Amato 2010). Separated parents may experience stress from a decline of emotional support, increased frequency of conflict with the ex-partner or financial insecurity. Any number of other typical sources of parental stress can arise, such as multiple family transitions after the separation or divorce, a change of domicile, or a new job. For children, the decline of parental support and guidance, the reduction or the loss of contact with one parent, continuing conflicts between parents or economic decline can cause stress that undermines well-being. Other typical sources of post-separation stress also threaten children's well-being: a change of schools, a change of home, loss of friends, or the addition of a new stepparent.

Protective factors also influence separation and divorce outcomes. The action both of stressors and protective factors helps explain why children's reactions to separation and divorce are highly variable. Moreover, studies often use the selection perspective, which hypothesizes that some individuals carry traits that increase the likelihood that they will end up divorced or as single parents, to augment the divorce-stress-adjustment perspective (e.g., Amato 2000; Sweeney 2010). The well-being of children living in single-parent and stepfamilies is protected by factors that include available resources (individual, interpersonal, structural), the subjective meaning and normative connotation of separation and divorce as well as socio-demographic characteristics including the child's gender, the number of biological and stepsiblings, and the age of the child both at the time of parental separation and at the time when the stepfamily is established (e.g., Booth et al. 2010; Pryor 2008; Rodgers and Rose 2002; Turunen 2013). Other factors, for example a high degree of co-parenting among the adults involved or children's participation in decision making, can also serve to reduce post-separation stress and increase child well-being.

Finally, increasing attention has been paid to residence and custody arrangements among separated families and to the stressors and protective factors associated with them. In many cases, a separation or divorce leads to a significant reduction or loss of father-child contact (e.g., Smyth et al. 2004; Swiss and Le Bourdais 2009). This may reduce stress if it eliminates family conflict. Yet the loss of contact is also associated with a reduction of children's resources. Because paternal involvement in parenting has strongly increased overall during recent years (Williams 2008), fathers now more commonly maintain contact with their children after separation (Westphal et al. 2014). The number of working mothers who divide parenting responsibilities with the father, both before and after separation, has also increased. Together, these trends are leading to an increased number of post-separation, multi-household family structures, which bring about challenges of various kinds for all family members and are thus also likely to affect individuals' health and well-being. 


\section{Childhood Circumstances and Later Life Health}

Next to the effects of family structure on child well-being described in the previous section, various aspects of individuals' childhood circumstances have been suggested to exhibit a lasting impact on adult health. On the one hand, adverse macro-level conditions during childhood, reflected by, for example, high infant mortality rates or economic recession seem to matter for later life health and mortality (e.g., Delaney et al. 2011; van den Berg et al. 2009). On the other hand, micro-level conditions closely related to the individual's family backgroundparticularly early health and parental socio-economic status (SES) - have been shown to be important. ${ }^{3}$

These factors may affect later health directly or indirectly. On one hand, early nutritional deprivation, for example, might directly initiate negative health trajectories during the individual's childhood, which may persist or even aggravate during the ageing process, independent of adult SES ('latency model'; e.g., Huang et al. 2011; Zhang et al. 2008). On the other hand, poor health and economic deprivation in childhood might impact later life health indirectly through impaired adult socioeconomic attainment ('pathway model'; e.g., Case et al. 2005; Haas 2008).

Next to showing a consistently negative correlation between low early-life SES and self-rated health in adulthood, studies also revealed a significant relationship between childhood SES and older adults' risk of suffering from functional limitations (e.g., Haas 2008; Huang et al. 2011; Wen and Gu 2011), cognitive impairment (e.g., Wen and Gu 2011; Zhang et al. 2008), as well as chronic conditions and depressive symptoms (e.g., Luo and Waite 2005; Pavela and Latham 2016). Along the same lines, poor childhood health was shown to have long-term negative effects on, for example, individuals' functional status (e.g., Haas 2008; Huang et al. 2011) and chronic health conditions (e.g., Blackwell et al. 2001; Haas 2007). Despite being correlated with each other, early health and SES also appear to bear independent associations with adult health. Research by Case et al. (2005), for example, indicated that even if parents' income, education, and social class are controlled for, adults who suffered from poor childhood health exhibit significantly worse health outcomes than adults who did not experience poor health during their childhood (also see Blackwell et al. 2001; Haas 2007).

\section{Intergenerational Family Relations and Health}

Intergenerational family relations might impact individuals' health just as health might affect intergenerational relationships in the family. In the following, we consider both causal directions as well as different dimensions of 'intergenerational

\footnotetext{
${ }^{3}$ See Brandt et al. (2012) for a more comprehensive overview of the related literature and a joint empirical consideration of (contemporary) contextual and life-course (childhood) factors impacting later life health.
} 
solidarity' (e.g., Bengtson and Roberts 1991) and well-being (physical and psychological health); also see Steinbach and Hank (2015).

The family social network constitutes, on the one hand, an important resource to protect individuals' health by, for example, reducing psychosocial stress and increasing one's overall well-being (e.g., Antonucci et al. 2007; Franks et al. 1992). Low relationship quality between parents and adult children (e.g., An and Cooney 2006; Koropeckyj-Cox 2002) or burdens associated with providing care to kin (e.g., Call et al. 1999; Sherwood et al. 2005), on the other hand, have been shown to result in health deterioration, especially if psychological well-being is considered. The individual's trust in the family network as a potential source of support and the emotional stability of family relations appear to be particularly important here. Some evidence suggests that the subjective perception of support might even be more relevant for individuals' health than the actual support one has (or has not) received (e.g., Antonucci 2001).

Whereas emotional closeness and relationship quality strongly influence the well-being of parents and adult children (e.g., Merz et al. 2009a, b), geographic proximity and frequency of contact appear to be unrelated to older parents' life satisfaction - at least if the exchange of instrumental support is controlled for (see Lowenstein et al. 2007). This latter finding underlines the importance of distinguishing between emotional support (including closeness and relationship quality) on the one hand, and instrumental support on the other hand. The former not only seems to be more beneficial for both generations in the family, but receipt of the latter may even reduce one's well-being (e.g., Merz and Consedine 2009; Merz et al. 2009b; also see Bordone 2015). This kind of adverse effect seems most likely in situations characterized by a strong imbalance in the exchange of intergenerational support (e.g., Lowenstein et al. 2007; Pillemer et al. 2007).

A large and growing number of empirical studies assess the impact of family relations on health beyond the parent-child-relationship, taking a three-generational perspective. Their results suggest a positive relationship between caring for one's grandchildren and a variety of physical and psychological health outcomes (Arpino and Bordone 2014; Di Gessa et al. 2016a, b; Hughes et al. 2007; Mahne and Huxhold 2015). Moreover, focusing on the role of the relationship to grandparents in the well-being of adolescent and young adult grandchildren, Ruiz and Silverstein (2007) showed that grandchildren benefit from a close relationship to their grandparents as well, especially if they are living in a non-traditional family context. This result is corroborated by a more general finding suggesting that grandparents are more likely to step in and provide help, if the middle generation's resources are limited, making grandparents support an all the more important resource for (grand-)children's health (e.g., Arránz Becker and Steinbach 2012; McIlvane et al. 2007).

Health, however, is not only affected by characteristics of intergenerational family relations, but is also a determinant of the latter. Good health may be an important resource to provide intergenerational support, whereas poor health might often trigger the need to establish an exchange of instrumental and/or financial support between generations in a family. It is therefore surprising that so far only 
relatively little empirical research has been conducted yet addressing this causal direction of the intergenerational relations and health nexus. Health outcomes are often merely treated as control variables in multivariate models, without much theoretical or thorough empirical consideration of possible underlying mechanisms. Longitudinal analyses in particular are missing-despite the obvious relevance of the question as to which extent changes in the individual's health status might affect various dimensions of intergenerational relationships.

Cross-sectional findings suggests that good (poor) health in both the parents' and the children's generation is positively (negatively) associated with reports of relationship quality (e.g., Rossi and Rossi 1990; Steinbach and Kopp 2010; Szydlik 2000). A longitudinal study by Merz et al. (2009a) supports the notion that the observed cross-sectional associations indeed reflect a causal effect of health on the intergenerational relationship. Stress has been put forward as a possible explanation for this: Health deterioration causes stress in parents and children, which eventually affects relationship quality in negative ways. Whereas changes in parents' health status appear to be unrelated to the frequency of contact with adult children (Ward et al. 2014), studies have found the expected changes in instrumental support: Those in poorer health - especially parents - are more likely to receive and less likely to provide help (e.g., Chan and Ermisch 2012; also see Ogg and Renaut 2013). Both parents and children are sensitive to the other generation's needs and variations across the life course (cf. Grundy 2005).

\section{Conclusions and Future Directions}

The evidence reviewed in the previous sections suggests that family matters greatly - and in various ways - for individuals' health across the entire life-course: from early childhood, through adulthood, to very old-age. Our review has also shown that the investigation of the multifaceted family-health-nexus is a flourishing field for empirical research in various social science disciplines (sociology, social epidemiology, demography, etc.). The increasing availability of high-quality international data sets providing detailed information on individuals' social (i.e. family) and health circumstances has spawned a plethora of studies beyond the US context. Even if many of the associations reported above appear to be fairly universal, it is still seems useful to corroborate these findings in a variety of societal settings. Europe - with its diversity of welfare, family, and other kinds of 'regimes' - has been fairly well-covered to date (except for many Eastern European countries) and our knowledge about the interrelationship between families and health in Asia (especially China) is also growing rapidly.

We conclude our review of the current state of the art with a (selective) outlook on what we consider to be some promising - and necessary - issues for future research: 
- Partnership biographies and family structures have become increasingly complex. Empirical analyses should thus not only consider individuals' legal marital status and biological children, but they also need to account more generally for partnership or relationship status (e.g., Schneider et al. 2014) as well as for 'social' parenthood (e.g., Kravdal et al. 2012).

- Further investigations of biological risks (such as cardiovascular risk) and their associations with family circumstances (such as marital biography or marital quality; e.g., Liu and Waite 2014; McFarland et al. 2013) are likely to improve our understanding of the pathways to disease and disability.

- Although there is some evidence for spouses' concordance in health and well-being (see Walker and Luszcz 2009, for a review), relatively little attention has been paid so far to the various pathways through which other family members' health might be consequential for one's own health (e.g., Roth et al. 2015; Valle et al. 2013) or for other important outcomes, such as economic well-being (e.g., Heflin and Chiteji 2014).

- Last but not least, population aging draws our attention to the role of family ties in older people's health (e.g., Ryan and Willits 2007; Waite and Das 2010). This, however, should not ignore that the foundations for 'successful aging' are laid out very early in life and that family background (e.g. parental socio-economic status) is a crucial factor (e.g., Brandt et al. 2012; Schaan 2014).

\section{References}

Aitken, Z., Garrett, C. C., Hewitt, B., Keogh, L., Hocking, J. S., \& Kavanagh, A. M. (2015). The maternal health outcomes of paid maternity leave: A systematic review. Social Science and Medicine, 130, 32-41.

Alonzo, A. A. (2002). Long-term health consequences of delayed childbirth: NHANES III. Women's Health Issues, 12, 37-45.

Amato, P. R. (2000). The consequences of divorce for adults and children. Journal of Marriage and Family, 62, 1269-1287.

Amato, P. R. (2010). Research on divorce: Continuing trends and new developments. Journal of Marriage and Family, 72, 650-666.

An, J. S., \& Cooney, T. M. (2006). Psychological well-being in mid to late life: The role of generativity development and parent-child relationships across the lifespan. International Journal of Behavioral Development, 30, 410-421.

Antonucci, T. C. (2001). Social relations: An examination of social networks, social support and sense of control. In J. E. Birren \& K. W. Schaie (Eds.), Handbook of the psychology of aging (5th ed., pp. 427-453). New York: Academic Press.

Antonucci, T. C., Jackson, J. S., \& Biggs, S. (2007). Intergenerational relations: Theory, research, and policy. Journal of Social Issues, 63, 679-693.

Arránz Becker, O., Loter, K., \& Becker, S. (2017). Familie und Gesundheit. Ein methodenkritischer Blick auf die aktuelle Forschung. In M. Jungbauer \& P. Kriwy (Eds.), Handbuch Gesundheitssoziologie (pp. 1-27). Springer.

Arránz Becker, O., \& Steinbach, A. (2012). Relations between grandparents and grandchildren in the context of the family system. Comparative Population Studies-Zeitschrift für Bevölkerungswissenschaft, 37, 543-566. 
Arpino, B., \& Bordone, V. (2014). Does grandparenting pay off? The effect of childcare on grandparents' cognitive functioning. Journal of Marriage and Family, 76, 337-351.

Bengtson, V. L., \& Roberts, R. E. L. (1991). Intergenerational solidarity in aging families: An example of formal theory construction. Journal of Marriage and the Family, 53, 856-870.

Blackwell, D. L., Hayward, M. D., \& Crimmins, E. M. (2001). Does childhood health affect chronic morbidity in later life? Social Science and Medicine, 52, 1269-1284.

Blomgren, J., Martikainen, P., Grundy, E., \& Koskinen, S. (2012). Marital history 1971-1991 and mortality 1991-2004 in England \& Wales and Finland. Journal of Epidemiology and Community Health, 66, 30-36.

Booth, A., Scott, M. E., \& King, V. (2010). Father residence and adolescent problem behavior: Are youth always better off in two-parent families? Journal of Family Issues, 31, 585-605.

Bordone, V. (2015). Est modus in rebus: A longitudinal study of intergenerational solidarity and Locus of Control. Ageing \& Society, 35, 1242-1277.

Brandt, M., Deindl, C., \& Hank, K. (2012). Tracing the origins of successful aging: The role of childhood conditions and social inequality in later life health. Social Science and Medicine, 74, $1418-1425$.

Brockmann, H., \& Klein, T. (2004). Love and death in Germany: The marital biography and its effect on mortality. Journal of Marriage and Family, 66, 567-581.

Call, K. T., Finch, M. A., Huck, S. M., \& Kane, R. A. (1999). Caregiver burden from a social exchange perspective: Caring for older people after hospital discharge. Journal of Marriage and the Family, 61, 688-699.

Carr, D., Springer, K. W., \& Williams, K. (2014). Health and families. In J. Treas et al. (Eds.), The Wiley Blackwell companion of to the sociology offamilies (pp. 255-276). Hoboken, NJ: Wiley.

Case, A., Fertig, A., \& Paxson, C. (2005). The lasting impact of childhood health and circumstance. Journal of Health Economics, 24, 365-389.

Chan, T. W., \& Ermisch, J. (2012). Intergenerational exchange of instrumental support: Dynamic evidence from the British household panel survey. http://dosen.narotama.ac.id/wp-content/ uploads/2012/03/Intergenerational-Exchange-of-Instrumental-Support-Dynamic-Evidencefrom-the-British-Household-Panel-Survey.pdf.

Christiansen, S. G. (2014). The association between grandparenthood and mortality. Social Science and Medicine, 118, 89-96.

Deindl, C., Brandt, M., \& Hank, K. (2016). Social networks, social cohesion, and later-life health. Social Indicators Research, 126, 1175-1187.

Delaney, L., McGovern, M., \& Smith, J. P. (2011). From Angela's ashes to the Celtic Tiger: Early life conditions and adult health in Ireland. Journal of Health Economics, 30, 1-10.

Di Gessa, G., Glaser, K., \& Tinker, A. (2016a). The impact of caring for grandchildren on the health of grandparents in Europe: A lifecourse approach. Social Science and Medicine, 152, 166-175.

Di Gessa, G., Glaser, K., \& Tinker, A. (2016b). The health impact of intensive and nonintensive grandchild care in Europe: New evidence from SHARE. Journal of Gerontology: Social Sciences, 71, 867-879.

Dupre, M. E., \& Meadows, S. O. (2007). Disaggregating the effects of marital trajectories on health. Journal of Family Issues, 28, 623-652.

Doblhammer, G. (2000). Reproductive history and mortality later in life: A comparative study of England and Wales and Austria. Population Studies, 54, 169-176.

Evenson, R. J., \& Simon, R. W. (2005). Clarifying the relationship between parenthood and depression. Journal of Health and Social Behavior, 46, 341-358.

Fletcher, J. (2012). The effects of teenage childbearing on the short and long-term health behaviors of mothers. Journal of Population Economics, 25, 210-218.

Franks, P., Campbell, T. L., \& Shields, C. G. (1992). Social relationships and health: The relative roles of family functioning and social support. Social Science and Medicine, 34, 779-788.

Greenfield, E. A. (2010). Child abuse as a life-course social determinant of adult health. Maturitas, $66,51-55$. 
Grundy, E. (2005). Reciprocity in relationships: Socio-economic and health influences on intergenerational exchanges between third Age parents and their adult children in Great Britain. The British Journal of Sociology, 56, 233-255.

Grundy, E. (2009). Women's fertility and mortality in late mid-life: A comparison of three contemporary populations. American Journal of Human Biology, 21, 541-547.

Grundy, E., \& Foverskov, E. (2016). Age at first birth and later life health in Western and Eastern Europe. Population and Development Review, 42, 245-269.

Grundy, E., \& Kravdal, Ø. (2008). Reproductive history and mortality in late middle age among Norwegian men and women. American Journal of Epidemiology, 167, 271-279.

Grundy, E., \& Kravdal, Ø. (2010). Fertility history and cause-specific mortality: A register-based analysis of complete cohorts of Norwegian women and men. Social Science and Medicine, 70, $1847-1857$.

Grundy, E., \& Read, S. (2015). Pathways from fertility history to later life health: Results from analyses of the english longitudinal study of ageing. Demographic Research, 32, 107-146.

Grundy, E., \& Tomassini, C. (2005). Fertility history and health in later life: A record linkage study in England and Wales. Social Science and Medicine, 61, 217-228.

Grundy, E., van den Broek, T., \& Keenan, K. (2017). Number of children, partnership status, and later-life depression in Eastern and Western Europe. Journal of Gerontology: Social Sciences [advance online access].

Guertzgen, N., \& Hank, K. (2018). Maternity leave and mothers' long-term sickness absenceevidence from West Germany. Demography (forthcoming).

Haas, S. A. (2007). The long-term effects of poor childhood health: An assessment and application of retrospective reports. Demography, 44, 113-135.

Haas, S. A. (2008). Trajectories of functional health: The 'long arm' of childhood health and socioeconomic factors. Social Science and Medicine, 66, 849-861.

Hank, K. (2010). Childbearing history, later-life health, and mortality in Germany. Population Studies, 64, 275-291.

Hank, K., \& Wagner, M. (2013). Parenthood, marital status, and well-being in later life: Evidence from SHARE. Social Indicators Research, 114, 639-653.

Hawkins, D. N., \& Booth, A. (2005). Unhappily ever after: Effects of long-term, low-quality marriages on well-being. Social Forces, 84, 451-471.

Heflin, C. M., \& Chiteji, N. (2014). My brother's keeper? The association between having siblings in poor health and wealth accumulation. Journal of Family Issues, 35, 358-383.

Henretta, J. C. (2007). Early childbearing, marital status, and women's health and mortality after age 50. Journal of Health and Social Behavior, 48, 154-266.

Henretta, J. C. (2010). Lifetime marital history and mortality after age 50. Journal of Aging and Health, 22, 1198-1212.

Henretta, J. C., Grundy, E., Okell, L. C., \& Wadsworth, M. (2008). Early motherhood and mental health in midlife: A study of British and American cohorts. Aging \& Mental Health, 12, 605-614.

Högnäs, R. S., Roelfs, D. J., Shor, E., Moore, C., \& Reece, T. (2017). J-curve? A meta-analysis and meta-regression of parity and parental mortality. Population Research and Policy Review, 36, 273-308.

Huang, C., Soldo, B., \& Elo, I. T. (2011). Do early-life conditions predict functional health status in adulthood? The case of Mexico. Social Science and Medicine, 72, 100-107.

Hughes, M. E., \& Waite, L. J. (2009). Marital biography and health at mid-life. Journal of Health and Social Behavior, 50, 344-358.

Hughes, M. E., Waite, L. J., LaPierre, T. A., \& Luo, Y. (2007). All in the family: The impact of caring for grandchildren on grandparents' health. The Journals of Gerontology Series B: Psychological Sciences and Social Sciences, 62, S108-S119.

Huijts, T., Kraaykamp, G., \& Subramanian, S. V. (2013). Childlessness and psychological well-being in context: A multilevel study on 24 European countries. European Sociological Review, 29, 32-47. 
Hurt, L. S., Ronsmans, C., \& Thomas, S. L. (2006). The effect of number of births on women's mortality: Systematic review of the evidence for women who have completed their childbearing. Population Studies, 60, 55-71.

Jeynes, W. H. (2006). The impact of parental remarriage on children: A meta-analysis. Marriage \& Family Review, 40, 75-98.

Kalmijn, M. (2008). The effects of separation and divorce on parent-child relationships in ten European countries. In C. Saraceno (Ed.), Families, ageing and social policy. Intergenerational solidarity in European welfare states (pp. 170-193). Cheltenham, Northampton, MA: Edward Elgar.

Kalmijn, M. (2013). Adult children's relationships with married parents, divorced parents, and stepparents: Biology, marriage, or residence? Journal of Marriage and Family, 75, 1181-1193.

Kalmijn, M. (2017). The ambiguous link between marriage and health: A dynamic reanalysis of loss and gain effects. Social Forces [advance online access].

Karraker, A., \& Latham, K. (2015). In sickness and in health? Physical illness as a risk factor for marital dissolution in later life. Journal of Health and Social Behavior, 56, 420-435.

Kendig, H., Dykstra, P. A., van Gaalen, R. I., \& Melkas, T. (2007). Health of aging parents and childless individuals. Journal of Family Issues, 28, 1457-1486.

Klaus, D., Nauck, B., \& Steinbach, A. (2012). Relationships to stepfathers and biological fathers in adulthood: Complementary, substitutional, or neglected? Advances in Life Course Research, 17, 156-167.

Koball, H. L., Moiduddin, E., Henderson, J., Goesling, B., \& Besculides, M. (2010). What do we know about the link between marriage and health? Journal of Family Issues, 31, 1019-1040.

Koropeckyj-Cox, T. (2002). Beyond parental status: Psychological well-being in middle and old age. Journal of Marriage and Family, 64, 957-971.

Koropeckyj-Cox, T., Pienta, A. M., \& Brown, T. H. (2007). Women of the 1950s and the 'normative' life course: The implications of childlessness, fertility timing, and marital status for psychological well-being in late midlife. International Journal of Aging and Human Development, 64, 299-330.

Kravdal, Ø., Grundy, E., Lyngstad, T. H., \& Wiik, K. A. (2012). Family life history and late mid-life mortality in Norway. Population and Development Review, 38, 237-257.

Kruk, E., \& Reinhold, S. (2014). The effect of children on depression in old age. Social Science and Medicine, 100, 1-11.

Kuh, D., Ben-Shlomo, Y., Lynch, J., Hallqvist, J., \& Power, C. (2003). Life course epidemiology. Journal of Epidemiology and Community Health, 57, 778-783.

Liu, H., \& Waite, L. (2014). Bad marriage, broken heart? Age and gender differences in the link between marital quality and cardiovascular risks among older adults. Journal of Health and Social Behavior, 55, 403-423.

Lorenz, F. O., Wickrama, K. A. S., Conger, R. D., \& Elder, G. H., Jr. (2006). The short-term and decade-long effects of divorce on women's midlife health. Journal of Health and Social Behavior, 47, 111-125.

Lowenstein, A., Katz, R., \& Gur-Yaish, N. (2007). Reciprocity in parent-child exchange and life satisfaction among the elderly: A cross-national perspective. Journal of Social Issues, 63, 865-883.

Luo, Y., \& Waite, L. J. (2005). The impact of childhood and adult SES on physical, mental, and cognitive well-being in later-life. Journal of Gerontology: Social Sciences, 60B, S93-S101.

Mahne, K., \& Huxhold, O. (2015). Grandparenthood and subjective well-being: Moderating effects of educational level. Journal of Gerontology: Social Sciences, 70, 782-792.

McFarland, M. J., Hayward, M. D., \& Brown, D. (2013). I've got you under my skin: Marital biography and biological risk. Journal of Marriage and Family, 75, 363-380.

McIlvane, J. M., Ajrouch, K. J., \& Antonucci, T. C. (2007). Generational structure and social resources in mid-life: Influences on health and well-being. Journal of Social Issues, 63, 759-773. 
Merz, E.-M., \& Consedine, N. S. (2009). The association of family support and wellbeing in later life depends on adult attachment style. Attachment \& Human Development, 11, 203-221.

Merz, E.-M., Schuengel, C., \& Schulze, H.-J. (2009a). Intergenerational relations across 4 years: Well-being is affected by quality, not by support exchange. The Gerontologist, 49, 536-548.

Merz, E.-M., Consedine, N. S., Schulze, H.-J., \& Schuengel, C. (2009b). Wellbeing of adult children and ageing parents: Associations with intergenerational support and relationship quality. Ageing \& Society, 29, 783-802.

Mirowsky, J. (2005). Age at first birth, health, and mortality. Journal of Health and Social Behavior, 46, 32-50.

Mirowsky, J., \& Ross, C. E. (2002). Depression, parenthood, and age at first birth. Social Science and Medicine, 54, 1281-1298.

Moonden, C. W. S., \& Uunk, W. J. G. (2013). For better and for worse: The relationship between union dissolution and self-assessed health in European panel data. European Journal of Population, 29, 103-125.

Moore, K. A., Murphey, D., Bandy, T., \& Lawner, E. (2014). Indices of child well-being and developmental contexts. In A. Ben-Arieh, F. Casas, I. Frønes, \& J. E. Korbin (Eds.), Handbook of child well-being. Theories, methods and policies in global perspective (pp. 2807-2822). Dordrecht: Springer.

Newton, N. J., Ryan, L. H., King, R. T., \& Smith, J. (2014). Cohort differences in the marriage-health relationship for midlife women. Social Science and Medicine, 116, 64-72.

O'Flaherty, M., Baxter, J., Haynes, M., \& Turrell, G. (2016). The family life course and health: Partnership, fertility histories, and later-life physical health trajectories in Australia. Demography, 53, 777-804.

Ogg, J., \& Renaut, S. (2013). Ageing and intergenerational support: The role of life course events. In A. Börsch-Supan, M. Brandt, H. Litwin, \& G. Weber (Eds.), Active aging and solidarity between generations in Europe (pp. 379-389). Berlin, Boston: de Gruyter.

Oswald, S. H., Heil, K., \& Goldbeck, L. (2010). History of maltreatment and mental health problems in foster children: A review of the literature. Journal of Pediatric Psychology, 35, $462-472$.

Pavela, G., \& Latham, K. (2016). Childhood conditions and multimorbidity among older adults. Journal of Gerontology: Social Sciences, 71, 889-901.

Perales, F., del Pozo-Cruz, J., \& del Pozo-Cruz, B. (2015). Long-term dynamics in physical activity behavior across the transition to parenthood. International Journal of Public Health, 60, 301-308.

Pillemer, K., Suitor, J. J., Mock, S. E., Sabir, M., Pardo, T. B., \& Sechrist, J. (2007). Capturing the complexity of intergenerational relations: Exploring ambivalence within later-life families. Journal of Social Issues, 63, 775-791.

Pryor, J. (2008). Children in stepfamilies: Relationships with nonresident parents. In J. Pryor (Ed.), The international handbook of stepfamilies. Policy and practice in legal, research, and clinical environments (pp. 345-368). Hoboken, NJ: Wiley.

Prosser, L. A., \& Corso, P. S. (2007). Measuring health-related quality of life for child maltreatment: A systematic literature review. Health and Quality of Life Outcomes, 5 (42).

Rapp, I., \& Klein, T. (2015). Familie und Gesundheit. In P. Hill \& J. Kopp (Eds.), Handbuch Familiensoziologie (pp. 775-790). Wiesbaden: Springer VS.

Rendall, M. S., Weden, M. M., Favreault, M. M., \& Waldron, H. (2011). The protective effect of marriage for survival: A review and update. Demography, 48, 481-506.

Rodgers, K. B., \& Rose, H. A. (2002). Risk and resiliency factors among adolescents who experience marital transitions. Journal of Marriage and Family, 64, 1024-1037.

Rossi, A. S., \& Rossi, P. H. (1990). Of human bounding. Parent-child relations across the life course. New York: Aldine de Gruyter.

Roth, D. L., Fredman, L., \& Haley, W. E. (2015). Informal caregiving and its impact on health: A reappraisal from population-based studies. The Gerontologist, 55, 309-319. 
Ruiz, S. A., \& Silverstein, M. (2007). Relationships with grandparents and the emotional well-being of late adolescent and young adult grandchildren. Journal of Social Issues, 63, 793 808.

Ryan, A. K., \& Willits, F. K. (2007). Family ties, physical health, and psychological well-being. Journal of Aging and Health, 19, 907-920.

Sasson, I., \& Umberson, D. J. (2014). Widowhood and depression: New light on gender differences, selection, and psychological adjustment. Journal of Gerontology: Social Sciences, 69, 135-145.

Schaan, B. (2013). Widowhood and depression among older Europeans-The role of gender, caregiving, marital quality, and regional context. Journal of Gerontology: Social Sciences, 68, 431-442.

Schaan, B. (2014). The interaction of family background and personal education on depressive symptoms in later life. Social Science and Medicine, 102, 94-102.

Schneider, B., Rapp, I., Klein, T., \& Eckhardt, J. (2014). Relationship status and health: Does the use of different relationship indicators matter? Global Public Health, 9, 528-537.

Sherwood, P. R., Given, C. W., Given, B. A., \& Von Eye, A. (2005). Caregiver burden and depressive symptoms analysis of common outcomes in caregivers of elderly patients. Journal of Aging and Health, 17, 125-147.

Shor, E., Roelfs, D. J., Bugyi, P., \& Schwartz, J. E. (2012a). Meta-analysis of marital dissolution and mortality: Reevaluating the intersection of gender and age. Social Science and Medicine, 75, 46-59.

Shor, E., Roelfs, D. J., Curelli, M., Clemow, L., Burg, M. M., \& Schwartz, J. E. (2012b). Widowhood and mortality: A meta-analysis and meta-regression. Demography, 49, 575-606.

Smyth, B., Caruana, C., \& Ferro, A. (2004). Father-child contact after separation. Profiling five different patterns of care. Family Matters, 67, 20-27.

Steinbach, A. (2013). Family structure and parent-child contact: A comparison of native and migrant families. Journal of Marriage and Family, 75, 1114-1129.

Steinbach, A., \& Hank, K. (2015). Familiale Generationenbeziehungen aus bevölkerungssoziologischer Perspektive. In Y. Niephaus, M. Kreyenfeld, \& R. Sackmann (Eds.), Handbuch Bevölkerungssoziologie (pp. 367-392). Wiesbaden: Springer VS.

Steinbach, A., \& Kopp, J. (2010). Determinanten der Beziehungszufriedenheit: Die Sicht erwachsener Kinder auf die Beziehungen zu ihren Eltern. In A. Ette, K. Ruckdeschel, \& R. Unger (Eds.), Potenziale intergenerationaler Beziehungen. Chancen und Herausforderungen für die Gestaltung des demografischen Wandels (pp. 95-116). Würzburg: Ergon.

Sudha, S., Mutran, E. J., Williams, I. C., \& Suchindran, C. (2006). Childbearing history and self-reported well-being in later life. Research on Aging, 28, 599-621.

Sweeney, M. M. (2010). Remarrige and stepfamilies: Strategic sites for family scholarship in the 21st century. Journal of Marriage and Family, 72, 667-684.

Swiss, L., \& Le Bourdais, C. (2009). Father-child contact after separation: The influence of living arrangements. Journal of Family Issues, 50, 623-652.

Szydlik, M. (2000). Lebenslange Solidarität? Generationenbeziehungen zwischen erwachsenen Kindern und Eltern. Opladen: Leske + Budrich.

Turunen, J. (2013). Family structure, gender, and adolescent emotional well-being. Journal of Divorce and Remarriage, 54, 476-504.

Umberson, D., Williams, K., Powers, D. A., Liu, H., \& Needham, B. (2006). You make me sick: Marital quality and health over the life course. Journal of Health and Social Behavior, 47, 1-16.

Valle, G., Weeks, J. A., Taylor, M. G., \& Eberstein, I. W. (2013). Mental and physical health consequences of spousal health shocks among older adults. Journal of Aging and Health, 25, $1121-1142$.

van den Berg, G. J., Lindeboom, M., \& Lopez, M. (2009). Inequality in individual mortality and economic conditions earlier in life. Social Science and Medicine, 69, 1360-1367. 
Waite, L., \& Das, A. (2010). Families, social life, and well-being at older ages. Demography, 47, S87-S109.

Walker, R. B., \& Luszcz, M. A. (2009). The health and relationship dynamics of late-life couples: A systematic review of the literature. Ageing \& Society, 29, 455-480.

Ward, R., Deane, G., \& Spitze, G. (2014). Life-course changes and parent-adult child contact. Research on Aging, 36, 568-602.

Wen, M., \& Gu, D. (2011). The effects of childhood, adult, and community socioeconomic conditions on health and mortality among older adults in China. Demography, 48, 153-181.

Westphal, S. K., Poortman, A.-R., \& Van der Lippe, T. (2014). Non-resident father-child contact across divorce cohorts: The role of father involvement during marriage. European Sociological Review, 30, 444-456.

Williams, S. (2008). What is fatherhood? Searching for the reflexive father. Sociology, 42, 487-502.

Xu, M., Thomas, P. A., \& Umberson, D. (2016). Marital quality and cognitive limitations in late life. Journal of Gerontology: Social Sciences, 71, 165-176.

Zhang, Z., Gu, D., \& Hayward, M. D. (2008). Early life influences on cognitive impairment among oldest old Chinese. Journal of Gerontology: Social Sciences, 63B, S25-S33.

Zheng, H., \& Thomas, P. A. (2013). Marital status, self-rated health, and mortality: Overestimation of health or diminishing protection of marriage? Journal of Health and Social Behavior, 54, $128-143$.

Open Access This chapter is licensed under the terms of the Creative Commons Attribution 4.0 International License (http://creativecommons.org/licenses/by/4.0/), which permits use, sharing, adaptation, distribution and reproduction in any medium or format, as long as you give appropriate credit to the original author(s) and the source, provide a link to the Creative Commons license and indicate if changes were made.

The images or other third party material in this chapter are included in the chapter's Creative Commons license, unless indicated otherwise in a credit line to the material. If material is not included in the chapter's Creative Commons license and your intended use is not permitted by statutory regulation or exceeds the permitted use, you will need to obtain permission directly from the copyright holder.

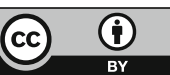

